\title{
江戸町人地における道空間の支配と管理体制
}

\section{GOVERNANCE AND MANAGIMENT OF STREET SPACES IN EDO COMMONERS DISTRICT}

\author{
高 橋 元 貴* \\ Genki TAKAHASHI
}

\begin{abstract}
Street spaces in the commoner district (choninchi) of Edo were maintained by shogunate officers - the town commissioner (machi-bugyo) and street commissioner (michi-bugyo). "Street space" is a concept that comprehensively covers the human and building environment that evolves along the street, in addition to the street itself. This paper gives a discussion of the maintenance and management of street spaces in Edo's commoner district. It diachronically clarifies how street spaces were governed by the shogunate between the $17^{\text {th }}$ and $18^{\text {th }}$ centuries and how its management system was established.
\end{abstract}

Keywords : Edo, Chonin-chi, Street Spaces, Maintenance, Machi-bugyo, Michi-bugyo 江戸, 町人地, 道, 維持管理, 町奉行, 道奉行

\section{1. はじめに}

江戸、ひいては日本の近世城下町の町人地における基礎的な単位 は、通りを挟んで両側に町家・町屋敷がならぶ「町」であった。町 の共同体としての社会的な関係性や空間的な一体性は、「道」を軸に とりむすばれていたといえる。また通りは、人々や物資、情報が行 き交い、商いが営まれる場でもあり、この意味で町は「道」を媒介 として外部世界に接続していたとも捉えられよう。そして、こうし た江戸における町人地内の道が、町に住む人びとによって維持管理 が担われていたことは早くから指摘されてきた ${ }^{1)}$

ただし、道は「公儀」の地所、つまり本来的には幕府の土地であ った。そのため幕府は、路上で展開される人びとの諸活動を取締り、 道の物的環境をも管理する立場にあり、道を統制するための都市法 令や建築規制など、近世を通して史料上に多数見出すことができる。

本稿では、江戸町人地における道空間の維持管理について論ずる。 そこでは、道そのものにくわえ、路上に存在し展開される物的かつ 人的な環境を包括的に捉えるため「道空間」という言葉を用いる。 つまり、町人地における道空間とは、町内の通りをはじめ、河岸地 や明地、広小路といった広義の道を意味し、言い換えれば、町屋敷 地＝沽券地以外の空間の総体をさす。

近年、日本近世史を中心に、城下町江戸における道をふくむ、イ ンフラストラクチャー（橋や上水など）の治安維持や空間管理とい った維持管理の実態が明らかにされつつあり、町や武家、寺社によ る負担関係からみた地縁的結合関係も検討されている2)。

町人地を対象とするものとしては、明地や河岸、木戸や番屋とい った町の共同体施設に注目し、幕府法令を中心に基礎的な事実を発 掘した伊藤好一氏による先駆的な研究がある ${ }^{3}$ 。とりわけ、広小路 や河岸地、町内の道について、その空間的様相をはじめ、用益と管
理をめぐる重層・複合的な権利関係の実態を明らかにした小林信也 氏の研究は、道空間の維持管理研究のひとつの到達点といえる4)。

筆者も特定の道空間（通りや広小路、河岸地など）における事例 分析から社会的、空間的実態をつぶさに追跡することは不可久と考 える。しかし、それらをいわば上から束ねる存在にあった公権力側 からの統制や管理といった問題は看過すべきではないだろう。

都市空間や建築に関わる法制度については、各種の建築制限や防 火政策（火除明地・土手の設定、塗屋・土蔵造の奨励）などの存在 が建築史分野でも早くから注目され、明暦大火後から享保期にかけ て集中して見出されることはよく知られている5)。これらは、近世 におけるひとつの規範とされたことは確実だが、その後の類似した 規制や統制については、その存在が指摘されるにとどまっている。

また、幕政史上の画期とされる天保の改革に関連・付随する道空 間をめぐる都市政策に関する研究蓄積もある ${ }^{6)}$ 。しかし、特定の道 空間の統制内容については明らかにされるものの、従前の支配や管 理体制との関連性はほとんど論じられない。こうした規制や政策は、 道空間という総合的な視角のもと、幕府による都市空間の支配や管 理体制の形成と変容のなかで考究されるべきではないか。

そこで本稿では、町人らの自律的な活動をなかば追認するような 幕府の態度をもみとめたうえで、町触などの基礎史料を中心としな がら、17 世紀半ばから 18 世紀末にかけての町奉行による町人地内 の道空間における支配と管理体制について通時的に明らかにするこ とを目的と寸る。こうした検討によって、個々の地域での維持管理 の実態や散発的に出されたかにみえる法制度や都市政策などの歴史 的位置づけを見直すための手がかりもえられると考える。

また本稿は、従来建築史学における都市史研究においてあまり主 題化されてきたとはいえない維持管理という行為を“都市空間をか
* 東京大学大学院工学系研究科建築学専攻 学術支援職員・修士(環境学)
Project Academic Support Staff, Dept. of Architecture, Faculty of Engineering, The University of Tokyo, M.Env. 
たちづける建築的営為” として捉え返すための方法論的試みのひと つでもある。

\section{2. 町人地における道空間の管理体制}

\section{1 町奉行と道奉行}

町人地における道空間は主に町奉行と道奉行によって管轄されて いた。ここではまず、両者の基本的性格を概観しておきたい。

町奉行は、町ないし町屋敷を社会的、空間的な単位としながら、 町人地におけるすべての行政・司法をつかさどる立場にあった。当 然、町人地における道空間の統制と管理もその職務に含まれていた。 道そのものの機能維持にあたる、路面の修繥や掃除 (「道造」)、下 水溝の浚渫や修復を町中へと命ずる町触は 17 世紀半ばから見出せ、 正保 5 （1648）年 2 月 21 日のものが史料上の初出である7)。これ によれば、道は町内で高低差がなく（家前の下水溝に排水がなされ るように) 中央部分を高く築立てること（「壱町之内高ひくなき様ニ 中高二築可申事」)、下水を定期的に浚渫すること（「下水并表之みぞ 滞なき様二所々二而こみをさらへ上ヶ可申候」）とされている。この 触の内容は近世を通じて規範とされたと考えられ、各町の家主、月 行事、名主らにその責が負わされた。

他方、いまひとつ重視されたのが治安の維持であった。この点に ついても同時期から町触が見出せ、町中に対し木戸や番屋といった 共同施設の設置が命じられ、町人らには見廻りによる町内の警備、 喧嘩口論や捨物などの異変処理、そして夜には町境に設けられた木 戸門を閉じることが義務づけられている 8)。さらに常時、路上への 水を溜めた桶の設置や、数町ごとに火の見櫓を建設させるなど、防 火対策もあわせて命じられる場合も少なくない。

このほか町触には、店前や河岸地への材木や薪といった商品高積 みに対する禁令や、町家を路上にまで張り出させて建設することに 対する規制なども存在し、これらも広義には道空間の統制に含まれ うる内容といえよう9)。

こうした大きくは機能維持と治安維持の二つに関わる町触は、継 続的に多様なかたちで見出せるが、寛文期（1661～72 年）を境に、 (1)「番」の徹底 (自身番・中番・辻番)、(2)手桶・水溜桶・のぼり梯 子の設置と修復、(3)道の修繕と掃除、材木類の高積や店前・軒先へ の積置の禁止の三ヶ条として整理されていったことが注目される 10)。これは明暦大火（1657 年）以後の防火政策であった火除明地・ 火除土手の設置、道幅規定や庇地制限などとも関わって、道空間の 管理が防火の基本と位置づけられることで内容が整えられていった ものと考えられる。延宝元（1673）年から正徳 2（1712）年までの 期間、毎年 9 月末に定式化された町触として触れられており、管理 に対する町奉行の基本姿勢が読み取れよう 11$)$

一方、町奉行とならんで町人地における道空間の管理にかかわる 重要な立場にあったのが道奉行である ${ }^{12)}$ 。幕府役人としては寬永 5 （1628）年に設置され、後述するように明和 5（1768）年に役職取 り放ちとされたが、その職務は、(1)道と下水の管理、(2)上水の管理、 (3)江戸近郊の屋敷地管理の三つであった。ただし、(2)元文 4(1739) 年に町奉行へ、(3)は正徳 3（1713）年に新地奉行（屋敷改）へと管 掌が移行されたことをふまえれば、もっとも基本となる職務は、(1) の道や下水の機能維持であったと考えてよいだろう。

道奉行衆による「町中道悪敷所」の取締り実施を町中へと通達す
る初出の触は万治 3 (1660) 年 9 月のものであるが 13)、統制内容に ついては、享保 5 （1720）年 11 月に道奉行が町中に対し提出をも とめた道空間管理に関寸る請書雛形からうかがえる ${ }^{14)}$ ここれは、町 内の道が「不陸」とならぬよう「家之前心掛ヶ」修繕し、下水溝に ついても定期的に浚渫することを各町に誓約させるもので、先述し た町奉行から出された道空間の機能維持に関わる町触と同内容のも のといえる。

とりわけ道奉行の性格を考えるうえで特筆される点は、城下町の 構成原理である町人地・武家地・寺社地・百姓地といった身分別の 居住領域とは無関係に職務が遂行できたことにある。すなわち、そ の対象は道や下水の機能に関寸る事項に限定されるものの、町人を はじめ、武家や寺社、百姓のいずれに対しても職権の行使が可能で、 この意味で江戸市中全域の道空間を統制する地位にあったのである。

このように町人地における道空間は、一義的には町奉行による管 轄のもと統制されていたといえるが、機能維持の局面をみれば町奉 行と道奉行とによる重層的な管理下におかれていたといえる。後述 するように、道空間を構成する物的環境に関していえば、町奉行、 道奉行の権限が交錯する状況にあった。

\section{2 道空間の維持管理体制としての町の「持場」}

町人地内における道空間の維持管理、つまり機能維持や治安維持 に関わる実際の管理業務は、その実施から費用負担にいたるまでを 町や町人によって担われていた ${ }^{15)}$

小林信也氏によれば、道には「持場」という空間的な負担区分が 設定されており、「両側町」であれば道全体が当該町の持場、通りを はさんで武家屋敷・寺社と向かいあうような「片側町」では道の中 央を境界とする地先の半分が町の持場とされ、反対側は武家や寺社 の持場とされた。こうした「持場負担」の原則は、通り沿いの町を はじめ寺社、武家にも敷衍化しえる江戸市中における普遍的な維持 管理体制であった ${ }^{16)}$

このように町人地における道空間は、町奉行と道奉行による統制 のもと、「持場」という分節された空間領域ごとに各町の責任によっ て実際の管理が行われ、維持されていたのである。

\section{3 「往還二相拘り候儀」の出願と認可}

以上を前提に、町奉行と道奉行による道空間の管理体制の具体相 を検討していきたい。

寛保元（1741）年 7 月、町年寄から年番名主らに対し、町人地の 道空間に関わること（「町々往還二相拘候儀」）で幕府の許可をえて 実施しているものにはどのようなものがあるか、またその出願先は どこか、というお尋衫がなされた ${ }^{17)}$ 。表 1 は名主らの返答書をまと めたもので、（a）道路工事、（b）木戸・番屋の新規建設、（c）既存 の木戸・番屋の修復、（d）町家普請時の板囲や土置場、出小屋の路 上への設置、(e) 下水溝の新規敷設と修復、(f) 路上への露店や作 業場、店前への日覆の設置や商品積み置きなど、の 5 項目があげら れている。

ここからまず特筆すべき点は、「古来」は（b）と（d）を除いて 「何方江も不申上」に各町の勝手で実施されていたことである。なお、 （d）については町奉行ではなく町年寄の許可が必要とされた。すな わち、寛保期にいたるまで、町や町人によって担われた道空間にお ける管理業務をはじめとする路上でのさまざまな建築行為を、幕府 はほとんど関知していなかったことになる。さらにここでは、木戸 
表 1 寛保元（1741）年前後における申請項目と出願先

\begin{tabular}{|c|c|c|c|}
\hline \multirow{2}{*}{\multicolumn{2}{|c|}{ 申請項目 }} & \multicolumn{2}{|r|}{ 出願先 } \\
\hline & & 古来 & 近来 \\
\hline \multicolumn{2}{|l|}{ 道造之事 } & なし & 町奉行+道奉行 \\
\hline \multicolumn{2}{|c|}{ 町内番屋并木戸新規願之事 } & 町奉行 & 町奉行 + 道奉行 \\
\hline \multicolumn{2}{|c|}{ 有来木戸番屋普請之事 } & なし & $\begin{array}{l}\text { 町奉行 }[* 1] \text { or } \\
\text { 町奉行 }[* 1]+\text { 道奉行 }\end{array}$ \\
\hline \multirow{2}{*}{\multicolumn{2}{|c|}{$\begin{array}{l}\text { 普請之内店前二土置場・板囲・出小屋之事 } \\
\text { 往還二有之下水落硧桝新規・修復等之事 }\end{array}$}} & 町年寄 & 町奉行 or 道奉行 \\
\hline & & なし & 道奉行 \\
\hline \multicolumn{2}{|c|}{ 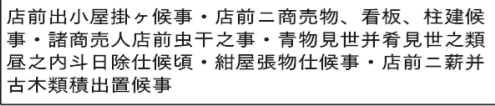 } & なし & 道奉行 $[* 2]$ \\
\hline \multirow{2}{*}{\multicolumn{4}{|c|}{ 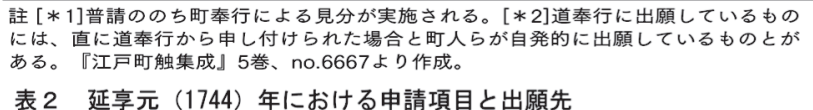 }} \\
\hline & & & \\
\hline & 申請項目 & & 出願先 \\
\hline \multicolumn{3}{|l|}{ 蔵願之事 } & 町奉行 \\
\hline \multirow{2}{*}{ 町橋之事 } & 新規井建直之儀 & & 町奉行 +道奉行 \\
\hline & 有来候を修復仕候儀 & & 町奉行 \\
\hline \multirow{2}{*}{ 番屋之事 } & 新規并建直之儀 & & 町奉行＋道奉行 \\
\hline & 有来候を修復仕候儀 & & 町奉行 \\
\hline \multirow{2}{*}{ 木戸・矢来之事 } & 新規并建直之儀 & & 町奉行 +道奉行 \\
\hline & 有来候を修復仕候儀 & & 町奉行 \\
\hline \multicolumn{3}{|l|}{ 井戸 - 上水之事 } & 町年寄 + 道奉行 $[* 1]$ \\
\hline \multirow{3}{*}{ 下水之事 } & 新規仕候儀 & & 町奉行 \\
\hline & 有来候を修復仕候儀 & & 出願なし \\
\hline & 下水往還江相掛り候分 & & 道奉行 \\
\hline \multicolumn{3}{|l|}{ 道造・車留之事 } & 町奉行 + 道奉行 \\
\hline \multicolumn{3}{|l|}{ 紺屋張物場建候事 } & 出願なし \\
\hline \multicolumn{3}{|l|}{ 店前虫干之事 } & 道奉行 \\
\hline \multicolumn{3}{|c|}{ 時節商物出小屋之事 } & 道奉行 [ $* 2$ 2] \\
\hline \multicolumn{3}{|c|}{ 土置場・板囲・普請中出小屋掛候事 } & 道奉行 \\
\hline \multicolumn{3}{|c|}{$\begin{array}{l}\text { 店前緑或八庇したみ等、往還江建出候場所又ハ戸袋之儀、看 } \\
\text { 梅等 }\end{array}$} & 町奉行 or 道奉行 \\
\hline
\end{tabular}

や番屋に関して「新規」と「有来」のものとが峻別され、後者につ いては出願が不要と町人らに認識されていた点は、町による道空間 の維持管理の実態を考えるうえでも興味深い。

そして「近来」になってようやく、幕府に出願し許可をえるかた ちとなったとされるが、申請項目によっては出願先が区々で、町人 地全体で出願方法が統一されていなかったことが明らかである。こ の点については、延享元（1744）年 4 月、さきと同内容のお尋叔が 町奉行から町年寄を通じて年番名主らへとなされており、この返答 書からより詳しい実態がうかがえる（表 2） 18)。

表 $1 \cdot 2$ から、「時節商物出小屋」、「店前虫干」、建物前面の造作 や張り出し（「往還へ建出候場所」）などは、道奉行だけに出願され ていたことがわかる。道奉行の本来的な職務は道や下水の機能管理 にあったが、これに付随して、往来に支障を来すような町人らのさ まざまな建築行為についても徐々に管理対象に組み込まれていった と考えられ、道奉行による見廻りの際に、町人らへと直に命じ、出 願が義務づけられたものと推定される。

一方、町橋や番屋、木戸・矢来などの新築（「新規并建直」）につ いては「両願」とされているが、「有来候」ものの修復については町 奉行所のみに出願された点も注目される。すなわち、現状を補修す るという狭義の意味での維持管理については、町奉行が把握、管理 することとされていたのである。

町内の通りでは、町家から庇が張り出し、営業時には店前に棚が 出され、道具や品物なども路上に積み置かれた。また、木戸や番屋、 井戸といった常設の町の共同施設をはじめ、場所によっては髪結床 や床店、臀筫張といった小商人らが営業する仮設的な施設もあった。 これらが、表 1 ・ 2 に具体的にみられる「往還二相拘リ候儀」とい ういささか茫漠とした言葉で括られる、道空間を構成するさまざま な物的要素である。18 世紀半ばごろから幕府は、これらの建設や設
置、修復にあたっては役所へ願い出ることを町人らに義務づけるこ とで道空間の統制を図ろうとしたといえよう。

ただし、こうした認可のあり方は、あくまでも幕府役人らの見廻 りによる指導や町による従来の維持管理実態を追認するものでしか なかったであろう。表にみられる「往還二相拘リ候諸願」の複雑な 様相は、このことを端的に示している。

2.4 小括

上述した道空間における不分明な管轄区分をめぐっては、実際の 管理上、町奉行と道奉行との間で弊害も生じていたようで、さきに みた町中に対する一連のお尋ねは、この問題に関わって町奉行が命 じた実態調査であったと考えられる。延享元年 4 月の名主らからの 返答ののち、「往還二相拘リ候儀」のすべてを町奉行所に出願すべき との旨が、町奉行から町年寄を介して町中へと申し渡されている。

この背景として、18 世紀半ばまでに江戸町方の急激な拡大があっ たことは重要であろう。すでに寛文 2（1662）年 11 月に上野・浅 草・芝あたりの旧代官所支配域が町奉行支配に編入されていたが 19) 正徳 $3(1713)$ 年 5 月「深川・本所・浅草・小石川・牛込・市谷・ 四谷・赤坂・麻布辺の御代官支配の内、町と名の付き候所」が支配 に組み込まれた 20)。つづいて延享 2 年 12 月には「寺社方え付き候 町家の分」(門前町家と境内町家) が新たに町奉行支配へと移管され た ${ }^{21)}$ 。こうした断続的な町方支配地の拡大が、町奉行と道奉行の管 理が「入跨」る大きな要因になったと考えられる。つまり延享元年 の「往還ニ相拘リ候諸願方」の調查は、さきにみた道空間における 入り組んだ管理のあり方の解消を町奉行が意図したものと理解でき るだろう。

町人地における道空間の管轄をめぐる問題は老中の裁許に委ねら れることとなった。延享元年 5 月、老中は「道筋之儀二付、町奉行 · 道奉行取計之儀は、前々之通双方申談可被取計候」と命じており 22)、 結果として町奉行の申渡は白紙とされた ${ }^{23)}$ 。こうした道空間の管理 体制における矛盾は、次節でみる道奉行廃止にともなって、町人地 そのものの支配という、より高次の問題へと帰着することとになる。

\section{3. 町人地における道空間の支配をめぐって 3.1 明和五年、道支配二付争論一件}

明和 5 （1768）年 9 月の道奉行罷免にともない、「道方之儀」（道 と下水）は普請奉行が管轄すること、これまで町奉行の管轄にあっ た「上水方之儀」も普請奉行の所管に移ることが町中へと申渡され た ${ }^{24)}$ 。そもそも普請奉行は、江戸城の石垣・堀の普請や修復、江戸 市中における拝領屋敷の授受などの土木事業を管掌する幕府役人で、 この移管は、江戸のインフラストラクチャーの管理を一元化するこ とが目指された都市政策であったと推定される。

ところが、その後の明和 $5 \sim 8 \quad(1768 \sim 70)$ 年にかけて、町人地 における「道方之儀」つまり町方における道空間の管轄権をめぐっ て町奉行と普請奉行との間で対立が起きた（「道支配二付争論一件」 と呼ぶ)。道空間の管轄移管は、町人地における包括的な権限が大き く制約される由々しき事態として町奉行に受け止められたことは間 違いない。また町人らにとっても、町屋敷と道とが管理上の理由か ら、それぞれ町奉行と普請奉行の管轄に空間的に分離されることが、 手続きの煩雑化にくわえ、日々の生活のうえでも多大な弊害を来す ものと考えられたことは容易に想像される。 
結論をさきに述べれば、この一件は、町人地における道空間に関 しては町奉行が管轄するというかたちで一応の決着がついたとみら れる。言い換えれば、江戸の武家地・寺社地における道空間のみを 普請奉行が管轄することになったのである。

ではこの一件の動向を概括しておこう。表 3 はこの間、町年寄を 通じて町奉行から年番名主らになされたお尋ねや申渡を整理したも のである。内容は、(1)多岐にわたる「往還ニ相拘リ候諸願」が誰に 対してなされてきたか、(2)町方支配の拡大にともなって町人地に含 まれることになった「町並地」の管轄についての大きく二つである。 後者は、年貢については代官所一上納しているが、そのほか「一射 は町方御支配」であることが確認されている。他方前者ついては、 おおむね出願先は町奉行所であったが、申請項目によっては道奉行 のみ、あるいは町奉行・道奉行への「両願」がみとめられ、これら は各町によっても「不同」であった。これは前節でみた通りである。

このなかで注目されるのは、明和 6（1769）年 7 月に町年寄から 年番名主らへなされた「五ヶ条御尋」である 25 )。これは、「所及御 堀端」(A)、「川筋之河岸」(B)、「柳原土手通り」(C)、「道橋」(D)、 「往来雨落外之分」 (E)の 5 つが、以前から普請奉行 (ないし道奉行) によって管理されているように見受けられるため、今後これらを普 請奉行の管轄（「普請方持場」）としても支障がないかを町人らへ問 いただすものであった。その後まもなく、名主らから町年寄へと返 答書（以下、返答書 $\alpha$ と呼ぶ）が提出されている。

ところで、これに先立つ同年 6 月、上と同内容の問い合わせが、 老中から町奉行に対してなされており、「五ヶ条」が幕府によって措 定されたものであったことがわかる。翌年の 3 月に町奉行から老中 宛に上申書が提出されている ${ }^{26)}$ ここには町年寄によってとりまと められた返答書（以下、返答書 $\beta$ と呼ぶ）も添えられており、これ はさきの返答書 $\alpha$ を加筆・修正したものである。

ふたつの返答書には、町人地全域におよぶ道空間の管理体制が詳 述されており、表 1 にみられた雑多なお尋衫に対する返答内容も含 まれていることから、この一件における町方（町奉行・町年寄・町 名主）の見解を総括するものとみられる。

老中の裁決がわかる史料は見出せていないが、明和 8（1771）年 5 月、道空間の管轄に関する町年寄からのお尋祇に対する年番名主 らの返答から、この一件の顛末がうかがえる ${ }^{27}$ )。返答書には「(引 用者注：一件）已来、町方持場之分は往来・道内共々諸事町奉行掛」、 すなわち、町奉行支配地内は、人びとの往来や道空間におけるすべ
ての事柄は町奉行が管理するものと述べられている。また「町御奉 行様御支配御屋敷附往還二而、町人共持場之儀」ともあり、解釈が 難しいが、町奉行支配地における道空間は町屋敷に付随する町人の 持場、つまり町が維持管理すべきものとされる。ここから、一件以 後、町人地の道空間は町奉行によって管轄（「支配」）されたと考え てよいだろう。

ただし、後に指摘するように、町人地の道空間における町奉行の 「支配」が確立されて以後も、その内実、つまり「往還二相拘リ候儀」 の管理体制が整備されたわけではなかった。

\section{2 町人地における道の空間類型}

以下「五ヶ条御尋」とその返答書を中心に考察をす寸める。まず 「五ヶ条」の内容を確認しておきたい。

A は「神田橋御門外方数寄屋橋御門外迠」「「元飯田町御堀端」、「数 寄屋橋御門外 $5 山$ 山御門、夫 5 土橋迠」、「幸橋御門外方虎御門外迠」、 「半蔵御門外御堀端」「四谷御門外 5 牛込御門外迠」の六つで、江戸 城堀沿いの道にあたる。この通りは、そのほかの堀川沿いの道 (B) とは区別され「御堀端」と称された。

B は町人地内を流れる堀川沿いの道（河岸地を含む）である。こ れは江戸中心部の「古町之川岸」と称される「日本橋川通、小舟町 伊勢町通、小網町通り、新材木町堀江町入川通、北新堀町霊岸島八 丁堀、鉄砲州築地、本材木町通り、中橋通、京橋通、木挽町三十間 堀通、土橋通、龍閑橋入川通、神田川通、米沢町辺浜町入川通」を はじめとする、浅草や芝など場末地域の堀川沿いの道にあたる。

C は、万世橋から浅草橋にいたる神田川南岸の土手通りである。 通り沿いには多くの武家屋敷が面していたが、床店や臀筫張といっ た小商人による古着屋が 300 軒ほども建ち並ぶ市場であった。

D は、市中に点在するいわゆる橋で、さいごの $\mathrm{E}$ は、字義通りに は「町家前の下水より外側部分の人びとが往来する場所」を意味し、 これは町内の通り一般をさす。ここには、火除地として設定された 幅広の道である広小路も含まれている。

これらは町人地に存在するすべての道空間である。すなわち、「五 ヶ条」とは、町人地に包摂される町家敷地以外の土地二道を、幕府 側が把握するための空間類型に他ならない。

\section{3 町奉行の支配と町による維持管理の関係性}

つづいて返答書の内容を検討していく。返答書には二種類が存在 したが $(\alpha$ と $\beta)$ 、両者ともに道空間の管轄権が町奉行にあることが 一貫して主張されており、論旨に大きな相違はない。差異について

\begin{tabular}{|c|c|c|c|c|c|}
\hline 年 & 月 & 日 & 内容 & 形式 & 史料 \\
\hline \multirow[t]{3}{*}{ 明和5 } & 09 & 05 & 道奉行、御役御免の申渡し & 町触 & 8105 \\
\hline & 09 & 16 & 「上水方之儀」および「道方之儀」が普請奉行の管轄となる旨の達し & 町触 & 8108 \\
\hline & 12 & 07 & 「町々番屋并商番屋」およひ「「其外商床」の新規建直しの際の出願先について & 尋十返 & 8121 \\
\hline \multirow[t]{7}{*}{ 明和6 } & 03 & 21 & 町方において「道造」を請け負っている者が、普請の際にどこに出願しているかについて & 厭十返 & 8133 \\
\hline & 06 & - & 「所々御堀端・川筋之河岸・柳原土手通・道橋・往還雨落其外之分」（以下「五ヶ条御尋」）が普請奉行の管轄となっても差し支えがないか。 & 尋 & $\star$ \\
\hline & 06 & 24 & 各町からの町奉行所以外の役所への届出および訴願については、かならず町奉行所へ訴え出るべき旨の達し & 町触 & 8147 \\
\hline & 07 & 24 & 「浅草末」および「本所」「深川」の「支配向」について & 尋十返 & 8150 \\
\hline & 07 & 24 & 浅草寺領町方の河岸地の「支配向」について & 尋十返 & 8151 \\
\hline & 09 & - & [8147] の再通達 & 町触 & 8166 \\
\hline & 11 & - & 「上水・道方之儀」に関する町奉行所以外への届出および訴願に関しての御下知 & 町触 & 8166 \\
\hline \multirow[t]{7}{*}{ 明和7 } & 01 & 17 & 延享4年の「明地・床店・其外見世物売囲居等取り払い」以後、幕府に「忠節」を申し出ることで床店設置が許可されている場所はあるかについて & 尋十返 & 8173 \\
\hline & 01 & 18 & 町方において「御入用」あるいは「請負人」、「武家方町方組合」によって「道造」を行っている場所があるか & 尋十返 & 8174 \\
\hline & 01 & 25 & 神田鍋町北横道町の六兵衛が「普請二付板囲」を町奉行よりも先に、普請奉行へ出願した件についてのお咞め & 町触 & 8175 \\
\hline & 02 & - & 町方での「道造」に関しては、以前は道奉行から直に申し付けられていたか、また道奉行へ出願していたか & 壽十返 & 8176 \\
\hline & 03 & - & 町奉行から老中への「五ヶ条御尋」に対する返答 & 返答書 & $\star$ \\
\hline & 04 & 09 & 町方にある高札について、どの役所に出願し建てたものか、また建替の節はどこに申し出ているか & 尋十返 & 8191 \\
\hline & & & 町々にて「商売物日覆」などを設置する際の出願先について & 尋十返 & 8192 \\
\hline
\end{tabular}


は後述することとし、ここでは分類ごとに内容を摘記する。

A) 所々御堀端：名主らの「詳伝」によれば、御堀端の石垣・小土手 際から三尺の場所までは古来より普請奉行の管轄とされ、それより 町屋敷側にある場所（「往還之儀」）はすべて町奉行が管轄すること となっています。具体的には、御堀端にある高札・火之見櫓・木戸・ 番屋などの普請・修復、路上での捨物・倒者・喧嘩口論などの異変 処理、御堀の中央より町家側に漂着した(「堀内中程 5 町屋二附候」) 浮物の処理などは、御堀端沿いの町が取り扱い、すべて町奉行所に 対して出願や訴願をしています。

B）川筋之河岸：「古町」の河岸地とは、町屋敷の間口に応じた地先 の堀川沿いの土地で、古来より町屋敷に付随するものとされてきま した (「河岸附町屋敷」)。これらは、町奉行所の管理下で、町人らに よって商売、営業のために利用され、町人の間では「株」のように 取り扱われてもいます。もし「河岸」(堀川沿いの道と河岸地）を普 請奉行が管理することになれば、諸手続きが煩雑化し、商品の值段 も狂い、「惣町中」にとって甚だ不利益なことと存じます。そのほか 浅草や芝地域などの河岸地については、町人らがそれぞれ町奉行や 普請奉行などに出願し古町同様の利用が許可されたものですが、そ の後、町奉行以外の幕府役人が関与した記録はいっさいありません。 C) 柳原土手 : 柳原土手通りや神田川に架けられた橋の橋台には多く の床番屋や床店、髪結床があります。これらは通り沿いの町や付近 の町人らが、それぞれ町奉行や普請奉行に出願し、設置が許可され たもので、営業の「御忠節」として、矢来の設置や「道造」、路上で の捨物・倒者の世話、柳の植替などを負担しています。「初発」には 町奉行以外の幕府役人の関与が認められ、通り沿いには武家屋敷が 面する場所もありますが、柳原土手通りの維持管理はす心゙て、町人 身分のものが行っております。それゆえ、出願や訴願はすべて町奉 行所に対するもので、「外御役所」が取り扱った記録はありません。 D) 道橋：町人地における橋は「御入用橋」（幕府によって計画・出 資、架橋された橋）と「町人持橋」(町人らによって計画・出資、架 橋された橋）とがありますが、どちらも古来より町奉行が管理して います。なお後者については、新規架け直しや修復の際には、町人 らが町奉行所に出願し、入札によって普請を実施しています。

E) 往来雨落其外之分 : 町内の道での捨物・倒者・喧嘩口論などにつ いては、古来より当該の町が処理し、そのつど町奉行所一訴え出て います。他方、町の共同施設の新規普請や修復、「道造」、これにと もなう「車留」の実施に関しては、道奉行にも訴え出ておりました。 しかしこれは、町奉行所に出願したうえでのことで、あくまでも町 奉行に命じられて行っていたものです。そのほか、市中にはいくつ かの広小路が存在し、そこでは請負人の差配のもと臀筫張や床店、 水茶屋などの仮設店舗が設けられ、路上では振売商人らが営業を行 っています。広小路の管理業務を委託される請負人をはじめ、営業 する小商人は町人身分のもので、町奉行所以外の役所が関与した記 録はありません。

このように返答書では $\mathrm{A} \sim \mathrm{E}$ における維持管理のあり方を確認す るとともに、路上に展開される諸施設設置の由緒なども仔細に記さ れたうえで、道空間の管轄権が町奉行にあることが説かれている。

ところで、二つの返答書には、叙述の仕方や含まれる事例に差異 が認められる。ひとつは、ごくわずかではあるが、普請奉行や道奉 行といった「外御役所」のみが関与した事例についての記述が削除
されている点である。いまひとつは、事情の複雑な場所については その内容が単純化され記載されている点である。このように返答書 $\beta$ では、返答書 $\alpha$ で雑然と綴られていた事実内容に添削がほどこさ れ、論点が整理されていることは看過す心゙きではないだろう。

たとえば、御堀端（A）や柳原土手 $(\mathrm{C}) 、$ 広小路（E）に存在し た番屋や商床、葭筫張の店は、町奉行以外の役人から許可をえて、 営業が行われている場合も少なくなかった。しかしこうした「外御 役所」の関与は「初発之儀」に限定され、道空間の維持の局面にお いては、町奉行の管理下にある点が強調されるものとなっている。

一方、「往還二拘リ候儀」については町奉行とならんで、道奉行に よっても管理されていたことは紛れもない事実であった。しかしこ れについては、町人地における町奉行の権限は道空間にもおよび (「町御奉行所御支配場八往還二而茂町御奉行御持」) 、そもそも道空 間を維持管理する人びとが、町奉行に管掌される「町人身分」であ ることが主張され、道奉行の職権はあくまでも「支配」とは異なる と寸る見解が追記されているのである。

\section{4 小活}

以上から抽出される町奉行による町人地内の道空間支配を根拠づ ける町方（町奉行・町年寄・名主）の論理は、つぎの二点にまとめ られるだろう。

（i）空間の論理：町人おける道空間の全体像は、幕府によって 5 つの空間類型として把握された。これらは、町方にとって本源的に 町屋敷とセットで捉えるべきものとされ（「町屋敷付往還」「沽券地 附往還」)、河岸通りや番屋・床店などが設置された土手通りや広小 路、橋などの広義の道も、町人地に包摂されるとした（「河岸附町屋 敷」、「町方二付候場所」)。こうした見解は、多様な形態で存在する 町人地内の広義の道を、あくまでも町人が居住する町屋敷地=沽券 地に付随する場所と位置づける空間的な理解といえよう。

(ii ) 身分の論理 : 道空間における実際の維持管理を担ったのは町人 身分の人びとであった。そして、彼らの負担は、さまざまな利用や 営業上の許認可に対する町奉行への助成（「忠節」）であるとする。 このように町人地の道空間は、身分制社会における支配-被支配関係 にもとづいて統制され、管理されるべきものと考えられたのである。

ところで、江戸の道空間のすべてが普請奉行の管轄になることは、 町奉行が管掌する空間的な範囲が、沽券地二町屋敷地の夕に限定さ れることを意味する。つまりこの一件には、近世城下町の形成にあ たっての根幹にすえられた身分制ゾーニングという都市空間支配の あり方を大きく変容させうる契機を孕んでいたと考えられる。しか し結果としては、江戸周縁部にまで展開し、散在していた町人地と いう空間領域が、道空間における町奉行による支配と町による維持 管理という関係性にもとづいて改めて定義され、身分制社会の論理 が貫徹されたのである。

\section{4. むすびにかえて}

町人地における道空間の管轄権が、町奉行にあることが確認され て後も、町奉行による道空間の管理体制が確立されたとはいえなか った。これはひとえに、明和の一件が、身分制社会の統治に関わる 都市空間支配に争点があって、町人地内の「往還二相拘リ候儀」の 実質的な管理体制の構築が企図されたものではなかったからに他な らない。最後に 18 世紀末に整備されることとなった町人地におけ 
表 4 寛政2（1790）年と寛政3（1791）年の申請項目と出願先

\begin{tabular}{|c|c|c|c|}
\hline \multicolumn{2}{|c|}{ 寛政2（1790）年 } & \multicolumn{2}{|l|}{ 寛政3（1791）年 } \\
\hline 申請項目 & 出願先 & 申請項目 & 出願先 \\
\hline 自身番屋 & 町奉行 $\rightarrow$ 普請奉行 & \multirow{3}{*}{ 木戸・番屋井駒寄䌆建など之儀 } & \multirow{3}{*}{ 町奉行 } \\
\hline 木戸 & 町奉行 $\rightarrow$ 普請奉行 & & \\
\hline 番屋 & 町奉行 $\rightarrow$ 普請奉行 & & \\
\hline 商床・商番屋 & 町奉行 $\rightarrow$ 普請奉行 or 町奉行 & \multirow{2}{*}{ （木戸・番屋并駒寄綎建など之儀） } & \multirow{2}{*}{ (町奉行) } \\
\hline 彭結床・髮結番屋 & 町奉行 $\rightarrow$ 普請奉行 or 町奉行 & & \\
\hline 道造 & 普請奉行 & 道造 & 普請奉行 \\
\hline 家前下水 & ? & 町方家前下水、右新規修復共 & 町奉行 \\
\hline 往還跨下水 & 町奉行 $\rightarrow$ 普請奉行 or 町奉行 & 町方往還横切下水、右新規修復共 & 普請奉行 \\
\hline 町方橋 & 町奉行＜wide>普請奉行［届］ & 町方持橋願 & 町奉行 \\
\hline- & - & 武家町組合橋願 & 普請奉行 \\
\hline 車留 & 町奉行 $\rightarrow$ 普請奉行 & 車留願 & 普請奉行 \\
\hline 火之見立梯子 & 町奉行 $\rightarrow$ 普請奉行 & 火之見建梯子并火之見櫓建候願 & 町奉行 \\
\hline 火之見櫓 & 町奉行 $\rightarrow$ 普請奉行 & 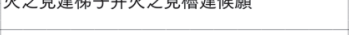 & \\
\hline 壁土置場 & 普請奉行 & 家前板囲・十置場願 & 町奉行 \\
\hline 板囲 & 普請奉行 & & \\
\hline 看板柱 & 普請奉行 & 看板柱建候願 & 町奉行 \\
\hline 紺屋干物場 & 普請奉行 & 紺屋共家前江物干柱建候願 & 町奉行 \\
\hline 虫干 & 普請奉行 or 町奉行 & 質屋共御用中家前江虫干致候願 & 町奉行 \\
\hline \multirow{4}{*}{$\begin{array}{l}\text { 家前并河岸地商物 } \\
\text { 積出之儀 }\end{array}$} & \multirow{4}{*}{ 普請奉行 } & 商ひもの家前江積置并日覆願 & 町奉行 \\
\hline & & 下水外流し仕付并駒奇矢来建候願 & 町奉行 \\
\hline & & 店前輪木建候願 & 町奉行 \\
\hline & & 町方河岸付石垣并川内江も懸り相当願 & 町奉行 \\
\hline- & - & 雛甲人形商ひ候内往還江小屋掛ヶ願 & 町奉行 \\
\hline- & - & 神事二付幟桃灯建候願 & 町奉行 \\
\hline- & - & 掘井戸之儀二付願 & 町奉行 \\
\hline- & - & 上水井戸普請など都而上水二付候願并届訴 & 普請奉行 \\
\hline
\end{tabular}

る道空間の管理体制について考察し、むすびにかえたい。

表 4 (左段) は、寛政 2 （1790）年 2 月に名主らが町奉行所に報

告した内容をまとめたものである ${ }^{28)}$ こここから、18 世紀末にいた るまで「往還二相拘リ候儀」が、まず町奉行所に出願し、許可をえ たうえで、普請奉行にも同様の出願を行うという「両願」のかたち であったことがわかる。さらに注目す心゙きは「道造」や「板囲」、「看 板柱」などが普請奉行にのみ出願されていたことである。これらは、

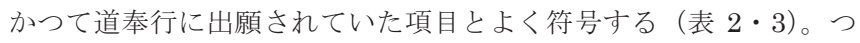
まり、出願と認可のあり方をみる限り、実際には道奉行の職務は普 請奉行へと引き継がれており、管理体制そのものはほとんど変わっ ていなかったのである。

翌年 4 月、「往還二相拘リ候諸願方」に関する取り決めが、町年 寄を通して町奉行から町中へと申渡されている（表 4 右段）29）。「道 造」や「車留」、「武家町組合持橋」、上水に関わること、道を跨いで 流れる下水については普請奉行へ出願し、そのほかはすべて町奉行 に出願すべきとされている。ここにようやく、出願先が町奉行と普 請奉行とに振り分けられ、町人地における道空間の管理体制＝「往 還二相拘リ候儀」の認可システムがかたちづくられたのである。

これに相前後して、将軍松平定信によって寛政改革がす寸められ、 その一環として町中へ「町法改正」が触れられたことはよく知られ

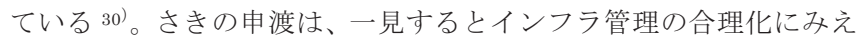
るが、幕府財政の安定化を目指した幕政改革との関係性のなかで捉 える必要があるだろう。つまりこれは、二重化していた「往還二相 拘リ候儀」の諸手続きを簡略化し、幕政ならびに町政双方にかかる 経費の軽減をねらったものとして理解されるべきであろう。この認 可システムは、道空間の積極的な管理政策ではなく、あくまでも経 済政策の副産物でしかなかったのである。

このことは、道のもつ本来的な機能の管理のみを普請奉行が担当 し、それ以外を町奉行が管掌するといった不自然な分割によく現れ ている。そもそも市中を縦横にはしる道を、身分制にもとづく空間 的枠組みのもとで管轄 ・管理する体制そのものに、根本的な矛盾が 内包されていたといえよう。それゆえ以降も、町屋敷と武家屋敷、
寺社境内が通りを隔てて隣接する場合、とりわけ道空間におけるそ れぞれの持場負担をめぐる混乱が生じたことは容易に想像される。 その分担のあり方は、奉行間での眯合をとおして即地的に判断、決 定された。江戸の道空間は、本稿でみたような管理体制のもと、社 会的にも空間的にも複雑な関係性のなかで維持されたのである。

注

1）後藤新平『江戸の自治制』(二末堂書店、1922 年)、幸田成友『江戸と大坂』 (冨山書房、1934 年)など。

2）とくに武家地研究において研究進展がみられ、岩淵令治『江戸武家地の研 究』(塙書房、2004 年)、藤村聡「近世後期における江戸武家屋敷の上水 · 橋々組合について」(『歴史学研究』682、1996 年)、松本剣志郎「江戸武 家屋敷組合と都市公共機能」(『関東近世史研究』57、2004 年)などがある。

3）伊藤好一『江戸の町かど』(平凡社、1986 年)。

4）小林信也『江戸の民衆世界と近代化』(山川出版社、2002 年)。

5）大熊喜邦「江戸時代住宅に関する法令と其影響」（『建築雑誌』420、1921 年)、内藤昌『江戸と江戸城』(鹿島出版会、1960 年)、水野耕嗣「近世都市 ・ 建築法制史の研究」（『学術講演梗概集』ほか、1975 2007 年)、玉井哲 雄『江戸ー失われた都市空間を読む』(平凡社、1986 年)など。

6）前掲註 3)・4)、藤田覚『遠山金四郎の時代』（校倉書房、1992 年）など 7）『江戸町触集成』第 1 巻、 2 号（塙書房、以下『江町触』と略記）など。

8)『同』第 1 巻、10、20 号など。

9)『同』第 1 巻、 $7 、 44$ 号など。

10）『同』第 1 巻、 $377 \cdot 465 \cdot 637 \cdot 687 \cdot 797$ 号など。定式化された町触の 初出は、延宝元年 9 月 28 日付（『江町触』第 1 巻、1146 号）。

11）管見の限り正徳 3 年以降は同内容の町触が見出せていない。これは後述 する町奉行支配地の拡大と関連すると考えられる。こうした 18 世紀におけ る江戸町方の拡大が、道空間における町奉行と道奉行との入り組んだ管理 体制と管轄権問題の大きな要因となっていたと推定される。

12）道奉行については松本剣志郎「江戸幕府道奉行の成立と職掌」（『地方 史研究』349、2011 年) を参照。

13)『江町触』第 1 巻、301 号。

14)『同』第 4 巻、 5685 号。

15）前掲註 1) - 3) - 4)

16）前掲註 3)。小林氏の江戸市中における道空間の維持管理体制＝「持場負 担論」については筆者も異論はないが、それぞれの「持場」が市中全域を 覆うように、あらかじめ幕府によって設定されたわけではなかったことに は留意すべきであり、その生成原理と持場の空間類型については検討の余 地があると考える。この点については今後の課題としたい。

17)『江町触』第 5 巻、 6667 号

18)『同』第 5 巻、 6677 号。

19)『同』第 1 巻、369 号。

20)『同』第 3 巻、 4721 号。

21)『同』第 5 巻、6756 号。

22)『享保撰要類集』6、蔵地商床道舗下水之部高積之事、第 72 件（旧幕府引 継書・国立国会図書館蔵、以下「旧幕」と略記）。

23) 延享元年 5 月 28 日、町年寄樽屋から年番名主らに対し「往還江相拘り候 諸願之儀」はこれまでと同様とし「先達而御内寄合二而年番江被仰渡候右 之儀（引用者注 : 町奉行所のみへの出願を命じた）御書付八、御用無之候」 と申渡されている（前掲註 18））。

24)『江町触』第 7 巻、 $8105 \cdot 8108$ 号。

25)『同』第 7 巻、 8152 号。

26)『明和撰要集』 7 上、道敷下水之部、第 2 件 (旧幕)。

27）『江町触』第 7 巻、8255 号。

28)『類集撰要』3、家作往還河岸地物置高積 十六ヶ条願、第 33 件（旧幕） 29）同上、第 $35 \cdot 36$ 件（旧幕）。

$30 ）$ 『撰要類集』9 10 、町法改正一件（旧幕）、『江町触』第 9 巻、9795 • $9822 \cdot 9826 \cdot 9832 \cdot 9858$ 号ほか。

付記）本稿は、拙稿「江戸における都市・内・領域としての道」（シンポジ ウム梗概集『道を介した交流と都市』日本建築学会 歴史・意匠委員会 都 市史小委員会、2013 年 12 月 18 日）、Genki TAKAHASHI, "Maintenance and Order of Street Space in Edo Commoners Area", Street Lives in World History, (GHC International Workshop, Hosei University, Tokyo, Jul. 10 $0^{\text {th }}$ 2015）の一部を割愛し、加筆・再構成したものである。 


\section{GOVERNANCE AND MANAGIMENT OF STREET SPACES IN EDO COMMONERS DISTRICT}

\section{Genki TAKAHASHI*}

* Project Academic Support Staff, Dept. of Architecture, Faculty of Engineering, The University of Tokyo, M.Env.

The streets of Edo's commoners district (choninchi) were maintained and managed by the townsmen who lived in the district. The shogunate, on the other hand, was responsible for controlling and managing the various activities conducted on the street. While the commoners, in other words the townsmen, led the actual maintenance work, the town commissioner (machi-bugyo) and street commissioner (michi-bugyo) were the shogunate officers in charge of supervising the work. The purpose of this paper is to diachronically illustrate the shogunate's governance and management system for street spaces in Edo's commoner district from the mid- $17^{\text {th }}$ to late- $18^{\text {th }}$ century. This paper uses the term "street spaces" to comprehensively describe the human and built environment that evolves along the street

The first section investigates the basic system of management by the town commissioner and street commissioner. It points out that until the mid- $18^{\text {th }}$ century, the shogunate was oblivious to the various maintenance and management activities carried out by the townsmen in street spaces. It was only afterwards that a management system for street spaces was established by the shogunate by mandating an application process for the various management and construction activities carried out on the street.

The following section analyzes the reasoning behind the town commissioner's control over street spaces in the commoners district, based on the conflict surrounding jurisdiction rights that arose with the abolition of the street commissioner system in 1768. One of the reasons given was based on the spatial logic that the streets in the commoners district belonged to the commoner's townhouses. Another was based on the social class system, in that street spaces were maintained by people of the commoner class and thus, jurisdiction rights over such matters should belong to the town commisioner. Afterwards, a system was established in which street spaces in Edo's samurai and temple/shrine districts were managed by the commissioner of engineering works (fushin-bugyo) while those in the commoners district were administered by the town commissioner.

Lastly, the paper concludes with a discussion on further improvements to the management system for street spaces in the commoners district from the period after the town commissioner's jurisdiction right was secured up until the end of the $18^{\text {th }}$ century. From this, an unnatural assignment of responsibilities becomes apparent, with the commissioner of engineering works responsible for all things related to the functions of the street itself and the town commissioner responsible for everything else. The paper finally points out the fundamental contradictions inherent in a management system based on a spatial framework founded in a social class system.

(2016 年 3 月 9 日原稿受理, 2016 年 7 月 29 日採用決定) 